\title{
Effect of different chickpea varieties on development of the pulse beetle, Callosobruchus chinensis (L.)
}

\author{
MOHAMMAD ABBAS AHMAD*, M.S. KHAN AND MEENA AGNIHOTRI
}

Department of Entomology, College of Agriculture, G.B. Pant University of Agriculture and Technology, Pantnagar, U.S. NAGAR (UTTARAKHAND) INDIA

\section{ARITCLE INFO}

Received : 02.02 .2016

Revised : 03.03 .2016

Accepted : 12.03 .2016

\section{KEY WORDS :}

Chickpea, Biology, Developmental period, Callosobruchus chinensis L.

*Corresponding author:

Email: abbasrau@rediffmail.com

\section{ABSTRACT}

Studies conducted on growth and development of the pulse beetle, Callosobruchus chinensis ( L.) on 11 chickpea varieties in Department of Entomology, G.B. Pant University of Agriculture and Technology Pantnagar during June- September, 2014 revealed that the fecundity of the pulse beetle female varied significantly on different chickpea varieties, minimum being on PBG 1 (59.0 eggs/100 seeds ) and maximum on PKG 1 (81.0 eggs/100 seeds). The development period for eggs (5.33-7.0 days), larva (17.0-18.67 days) and pupa (5.67-7.33 days) on different varieties did not differ significantly however, significant variation in the total development period from eggs to adult (28.6732.33 days) was recorded in different varieties. Similarly the growth index of the pulse beetle varied significantly on various varieties (0.52-0.71). The results of study showed that the chickpea variety PKG 1 was most suitable for growth and development of the pulse beetle.

How to view point the article : Ahmad, Mohammad Abbas, Khan, M.S. and Agnihotri, Meena (2016). Effect of different chickpea varieties on development of the pulse beetle, Callosobruchus chinensis (L.). Internat. J. Plant Protec., 9(1) : 233-236. 